\title{
Analysis of the Factors Influencing Willingness to Pay and Payout Level for Ecological Environment Improvement of the Ganjiang River Basin
}

\author{
Kai Xiong ${ }^{1,2}$, Fanbin Kong ${ }^{1}$, Ning Zhang ${ }^{3}$, Ni Lei ${ }^{4, *}$ and Chuanwang Sun ${ }^{5}$ \\ 1 Institute of Ecological Economics, Jiangxi University of Finance and Economics, Nanchang 330013, China; \\ xiongkaing@hotmail.com (K.X.); kongfanbin@aliyun.com (F.K.) \\ 2 College of Economics and Trade, Nanchang Institute of Technology, Nanchang 330099, China \\ 3 College of Economics, Jinan University, Guangzhou 510632, China; zn928@naver.com \\ 4 School of Public Administration, Faculty of Economics and Management, East China Normal University, \\ Shanghai 200062, China \\ 5 China Center for Energy Economics Research, School of Economics, Xiamen University, \\ Xiamen 361005, China; scw@xmu.edu.cn \\ * Correspondence: nlei@dem.ecnu.edu.cn
}

Received: 30 May 2018; Accepted: 20 June 2018; Published: 24 June 2018

\begin{abstract}
China has continuously stepped up its efforts to protect the ecological environment of the Ganjiang River Basin. The government has played a leading role, but the residents, who have also played an important role in this issue, are often overlooked. Consequently, it is necessary and urgent to study the willingness of the residents, who are the direct stakeholders, to pay for the protection of the ecological environment of the Ganjiang River Basin. Based on a survey of 773 households, this study examines the downstream residents' willingness to pay (WTP) and their payout levels. Using the payment card (PC) contingent valuation method (CVM), we measure the payment probability of the downstream residents and the amount they are willing to pay. Additionally, Heckman's two-stage model is adopted for exploring the influencing factors of the surveyed residents' WTP and payout levels and avoiding the possible presence of sample selection bias. The results showed that $75.03 \%$ of the surveyed residents are willing to pay for ecological compensation in the Ganjiang River Basin. The downstream residents are willing to pay an annual average amount of about $\$ 47.62$ /household for ecological compensation. The factors that significantly influence their WTP include the educational background, work type, residential location, and water quality and quantity. In the case of payout levels, the influencing factors include the education background, work type, household annual disposable income, and water quality and quantity. In addition, the factor of value recognition is marginal and significantly related to WTP and payout levels. The results of this empirical study have important policy implications and recommendations that the government should intensify its propaganda about the ecological value, increase investment in education, and establish a variety of ecological compensation payments, in order to protect and improve the ecological environment of the Ganjiang River Basin.
\end{abstract}

Keywords: ganjiang river basin; ecological compensation; willingness to pay; influencing factors; Heckman's two-stage model

\section{Introduction}

The ecological depravation of the river basin has become prominent, and has accompanied the rapid growth of China's economy [1,2]. Furthermore, due to the absence of an ecological structural compensation policy and linkage mechanism [3], the relationship between the upstream 
and downstream stakeholders has increasingly gotten worse [4]. After the central government put forward a strategy of ecological civilization construction [5], a series of ecological compensation measures for river basins was proposed. For example, at the end of 2015, Jiangxi Province introduced an implementation scheme (The Implementation Scheme of River Basin Ecological Compensation in Jiangxi Province (Trial)), which further increased ecological protection, in response to a tighter constraint on water resources, water pollution, and the serious situation of water degradation [6]. Such policies have to some extent ameliorated the ecological environment and improved the ecosystem of the river basin. However, most policies attach importance to the role of government control on the macroeconomy and market regulation mechanism, while ignoring the importance of stimulating public participation. Meanwhile, they pay close attention to the economic attributes of environmental products, while losing sight of the social and ecological attributes that are more likely to inspire public participation, which could affect the formulation and improvement of relevant policies. In April 2015, China issued a notice (The Notice of the State Council on the Action Plan for the Prevention and Control of Water Pollution), which outlined 10 specific requirements for water pollution control, and for the first time highlighted the importance of public participation [7]. The process of watershed ecological governance needs to consider the will of various stakeholders, especially third parties (i.e., the public). In February 2017, Document No. 1 (The Central Committee's Document No.1 of the Chinese Communist Party) put forward the issue of focusing on the pollution of rivers and lakes, and strengthening the construction of major ecological projects [8].

However, in the process of watershed ecological management, there are still some problems, such as the lack of public participation in some areas [9]. The Ganjiang River Basin is the most important river in Jiangxi Province [10]. This problem is especially obvious. The upstream of the Ganjiang River Basin is about 270.95 hectare (ha), and the annual ecological value is about $\$ 7996.33$ per ha [11]. Meanwhile, the upper reaches of the Ganjiang River Basin are mainly concentrated in Ganzhou City, which is located in the south of Jiangxi Province. Ganzhou has an excellent ecological environment where the forest coverage rate exceeds $76 \%$. However, the living standard of the residents is relatively low, and 8 of the 18 counties within the jurisdiction of Ganzhou City are designated as poverty-stricken counties at the state level. In addition, the water quality of the Ganjiang River Basin maintained a good level for a long time. In order to prevent the deterioration of water quality and further improve the ecological environment of the downstream area, the central and local governments continue to strengthen environmental protection to the upstream area of the Ganjiang River Basin, which limits the development of impoverished regions, and results in positive externalities. Although the government has paid a certain amount of compensation for the upstream, yet due to the lack of an effective compensation mechanism, the actual rights of subsistence and development of the upstream and downstream counties are different [12], which leads to a contradiction between regional economic development and environmental protection in the river basin. As a terminal experience of the water resource allocation program, public support for the policy will ultimately effect its implementation [13]. According to the principle of "Who Benefits Whom Compensation", the lower reaches of the Ganjiang River Basin should be paid as ecological compensation beneficiaries to make up for the benefits of the upper reaches to protect or improve the watershed ecological environment [14]. Although the Jiangxi provincial government has promulgated and implemented the compensation approach (Jiangxi Province Watershed Ecological Compensation Approach (Trial)), influenced by the promotion of "Jiangxi Example of Beautiful China", the calculation of the ecological compensation funds of the river basin is mainly on account of the cost (i.e., construction and maintenance costs) of the upstream area to protect the river basin environment. The calculation method does not take market factors and public participation into account, and the estimated compensation for the smaller funds may lead to a compensation effect, which may not be fully apparent. Therefore, since the upstream residents and the government have been engaged in environmental protection of the river basin, the downstream residents should pay for the positive externalities derived from these activities. Thus, it is necessary to evaluate the willingness to pay (WTP) of the downstream residents. Willingness to pay is used 
as the basis of ecological compensation, which can effectively solve the above problems [15], and it is also an important link for the construction of social and economic relations between upstream and downstream areas [16]. Additionally, it is helpful for the government to establish a watershed ecological compensation mechanism [17].

In this context, we try to explore the downstream residents' WTP and payout level on the basis of a field data survey. The survey was conducted by the Institute of Ecological Economics at the Jiangxi University of Finance and Economics once to twice a year from 2016 to 2017. This paper focuses on the following three questions to theoretically contribute to the policy initiatives of the Ganjiang River Basin: first, are downstream residents willing to pay for ecological protection; second, what is the payout level of the residents who are willing to pay; and third, what are the factors affecting the residents' WTP and payout level? Through the study of the above problems, we can provide some reference and support for the construction of an ecological compensation mechanism and for policy making. It is noteworthy that there are no studies focusing on the downstream residents' WTP for the preservation of the Ganjiang River Basin in China. Hence, this research would fill the gap in this area. The remainder of this article is arranged as shown below.

Section 2 reviews the relevant research about ecological compensation and the factors influencing residents' WTP and payout level. Section 3 elaborates on the data source and research method of this paper. Section 4 expounds and interprets the empirical results. Section 5 summarizes the article and puts forward some relevant policy suggestions

\section{Literature Review}

Watershed ecosystems are of vital importance to human beings [18]. In recent years, many scholars have done research on the beneficiarys' willingness to pay in regard to watershed ecological protection by adopting the contingent valuation method (CVM) [19]. Bhandari [20] has used the contingent valuation method to explore residents' WTP for the lower reaches of the Chure region of Nepal, and has found that beneficiaries living in the downstream of the river basin are willing to pay a higher amount for potable water services if the water quality can be guaranteed and sustainable. Moreno-Sanchez et al. [21] has adopted CVM to research the downstream residents' willingness to pay in the Andean watershed in Colombia, and the research results may help to design user-driven payment for ecological environment services (PES) schemes that meet the requirements of efficiency and equity objectives. Hecken et al. [22] has employed CVM to study residents' willingness to pay in the lower reaches of Matiguás, Nicaragua, and the study results reveal that a definite local consciousness of upstream-downstream interdependencies and a considerable WTP for improved drinking water services imply a successful PES. Li Chaoxian [23] used CVM to evaluate the WTP of residents who are living in the Changsha reach of the Xiang Jiang River Basin and used the structural equation model to further study the factors affecting the willingness to pay. Zhou Chen et al. [17] researched the residents who are living in the intake area of Zhengzhou City in the South-to-North Water Diversion Project. In this case, the Tobit model was employed to inquire into the factors affecting the willingness to pay. In addition, Guan Xinjian et al. [24] has studied the residents' willingness to pay for ecological protection of the Xiao Honghe River Basin. All of the above research results found that if the upstream environment gets better and better, the residents who are living in the downstream region have a strong willingness to pay. Thus, scholars have made great efforts in studying the residents' willingness to pay for the river basin.

Methodologically, Zhou and Li [17] used the Tobit model to analyze the influencing factors for residents' willingness to pay for the watershed services, and the results show that residents' individual heterogeneity were significantly related to the residents' willingness to pay. Zheng et al. [25] adopted the Probit model to study the influence factors for residents' willingness to pay for the Jinhua River Basin, and the empirical results reveal that the education levels and incomes have significant correlation with the residents' WTP. In general, previous studies mainly employed the Tobit [17], Probit [25], logistic [26] or structural equation models [23] to analyze the factors influencing the willingness to pay 
on the basis of the contingent valuation method. However, the disadvantage of the models is that the factors affecting the residents' willingness to pay and payout level cannot be examined simultaneously. Notably, the models could not eliminate the interference of "WTP $=0$ " samples while analyzing the influencing factors of the residents' payout level [27]. It is gratifying that Heckman's two-stage model is capable of solving the above problems and avoiding the sample selection bias [28]. More importantly, in terms of the research object, there are still a few studies on the beneficiaries' willingness to pay and the influencing factors in the case of the Ganjiang River Basin, which gives a major push to accelerate the construction of the "Jiangxi sample" of ecological civilization. Based on the above considerations, this paper analyzes the WTP and the payout level of the residents, who are living in the downstream section of the Ganjiang River, by using the payment card contingent value evaluation (CVM). The Heckman's two-stage model will be adopted to study the affecting factors of the residents' WTP and their payout level. We hope that this research can provide important supplementary value for formulating eco-compensation policies for the Ganjiang River Basin and a certain reference value for the application of ecological compensation policies for drainage areas in China.

\section{Data Sources and Research Methods}

\subsection{Study Area and Data Sources}

Ganjiang is situated in the middle-lower Yangtze region, which covers the entire Jiangxi Province from south to north [29]. The source of the river is from the west foothills of Wuyi Mountain on the border of Jiangxi and Fujian provinces [30,31]. Ganjiang is the largest river basin in the Poyang Lake water area [32], and the total length of the main stream is about $766 \mathrm{~km}$, which is also one of the seven tributaries of the Yangtze River [33,34]. This paper studies the influencing factors for the residents' WTP and payout level for the ecological protection of the Ganjiang River Basin. The main research areas are the lower reaches of the basin, including Le'an, Suichuan, Yongxin, Wan'an, Wanzai, Lianhua, Yuanzhou, Taihe, Jishui, Yongfeng, Fengcheng, Ji'an, Anfu, Xingan, Yifeng, Xiajiang, Shanggao, Shangli, Jingangshan, Jizhou, Qingyuan, Gao'an, Luxi, Xiangdong, Zhangshu, Xinjian, Anyuan, Nanchang, Fenyi, Donghu, Yushui, Xihu, Qingyunpu, and Qingshanhu (as shown in Figure 1).

The data applied in the study originated from the 2016 and 2017 residents' survey designed to evaluate beneficiaries' WTP for ecological protection in the lower reaches of the Ganjiang River Basin. The survey was administered through a face-to-face questionnaire, which concentrated on the public awareness of ecological compensation for the Ganjiang River Basin in Jiangxi Province. The face-to-face questionnaire was adopted primarily due to the relatively specialized questions that need to be elaborated, and we could recover a higher percentage of valid questionnaires by using this method [35]. More critically, the face-to-face questionnaire is an excellent way to enhance communication with the respondents and transmit messages [36], which are necessary for the contingent valuation method (CVM). In addition, a pilot test was used to determine the minimum number of respondents to ensure that a representative sample was taken. Simple random sampling was adopted in our pilot test, and we found that at least 384 respondents met the requirements. Through the pilot survey, we could also improve issues related to the questionnaire design, expression approach, payment vehicle, and so on [37].

The questionnaire was divided into the following four parts. Part one was the introduction of the background of the Ganjiang River Basin, which included its general background and characteristics, in order to make the surveyed residents clearly understand the current situation of the river basin. Part two consisted of demographic and social questions, which included the surveyed residents' age, gender, education, work type, and other information. Through this part of the questionnaire, we could get explanatory variables of the residents' willingness to pay and payout level. Part three was the presentation of the contingent valuation scenario and dichotomous questions for acquiring information related to the residents' willingness to pay and payout level. The last part was to get the residents' payment method. Through the survey, we found that the residents were more than willing to adopt 
the payment methods. This is valuable information for the government to formulate corresponding policies in the future. Table A1 in the appendix briefly shows the major questions and answers of the questionnaire.

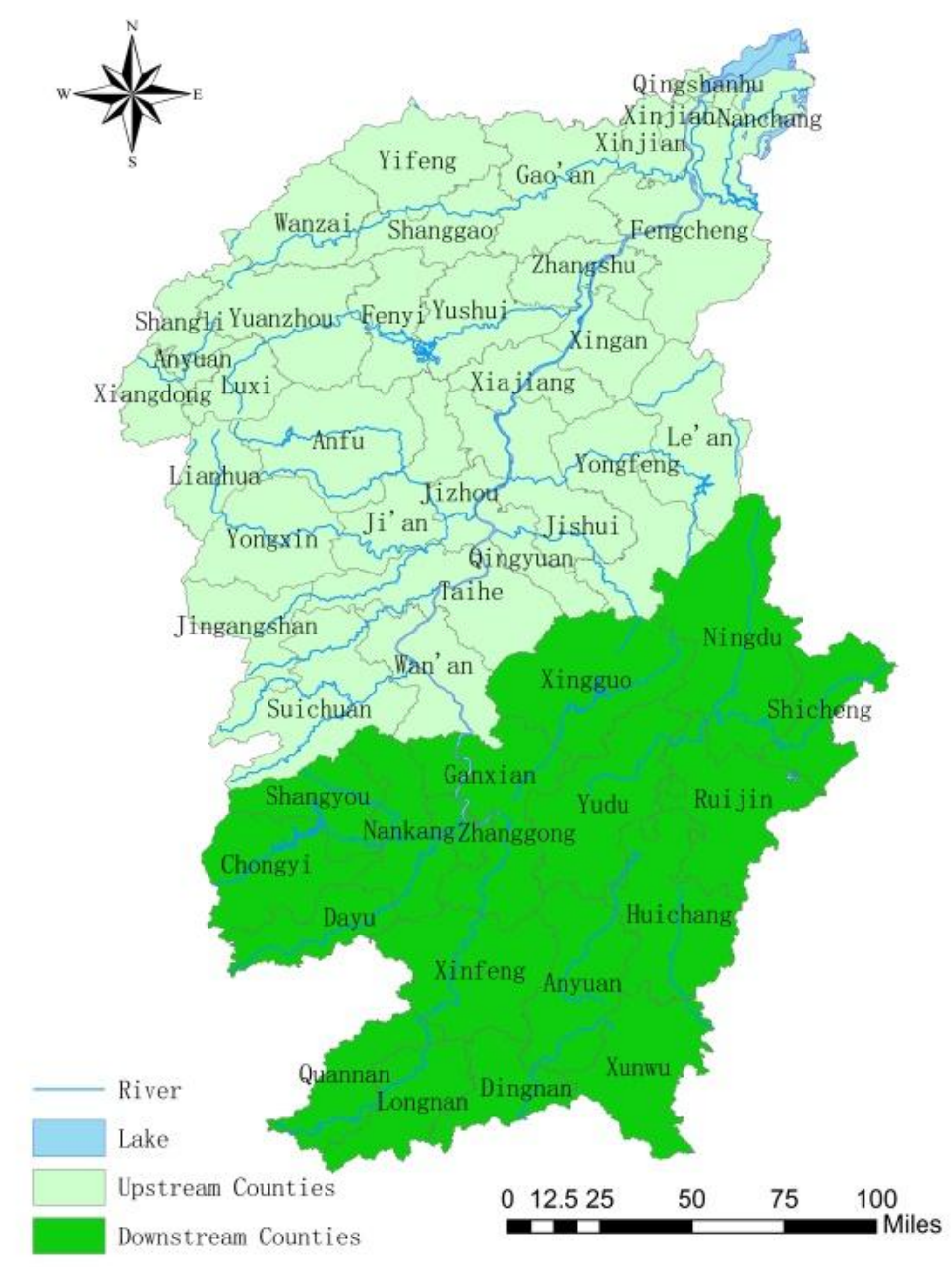

Figure 1. The schematic diagram of the Ganjiang River Basin.

For the purpose of facilitating subsequent comparative research, we acquired data from the "2016 Statistic Bureau of Jiangxi" and "Statistical Communique of the counties in the research areas on the 2015 National Economic and Social Development" and classified 34 counties into three types in terms of the per capita gross domestic product (GDP). The categories were demarcated as small, medium, and large depicting the following amounts: $<\$ 4500, \$ 4501-\$ 7400$, and $>\$ 7400$ (in order to make readers understand more clearly, we converted Chinese yuan into US dollars. Meanwhile, the value measured as the Chinese currency (RMB Yuan) is converted into US dollar value by the average exchange rate during 2016 (i.e., RMB 6.6423 yuan to one dollar) per household per year), respectively (as shown in Table 1).

The total population includes the residents living in the lower reaches of the Ganjiang River Basin. We chose simple random sampling for the pilot test and found that at least 441 respondents were required to meet the demand. In order to ensure that the investigation was unbiased and effective, we employed the three-stage sampling approach to conduct face-to-face investigations of 816 residents (Table 2).

In the first phase, we adopted a stratified sampling method to extract one town from each county (or district). In the second phase, the PPS (probability proportionate to size sampling) method was 
employed to select two villages (or neighborhoods) from every town that was chosen. In the third phase, we chose simple random sampling to pick 12 residents from the selected villages (or neighborhoods), and then we conducted a survey of the residents. Finally, 773 valid questionnaires that were found to provide reliable data were collected, which accounts for $94.73 \%$ of the total questionnaires. The number of valid questionnaires was larger than the required sample size; therefore, the various parameters estimated by the sample data can reflect the overall correlation characteristics.

Table 1. Classification of the research area.

\begin{tabular}{clcc}
\hline Type & \multicolumn{1}{c}{ Region } & Per Capita GDP \$) & Area \\
\hline \multirow{2}{*}{ I } & $\begin{array}{l}\text { Le'an, Suichuan, Yongxin, Wan'an, Wanzai, Lianhua, } \\
\text { Yuanzhou, Taihe, Jishui, Yongfeng, Fengcheng, Ji'an, Anfu, }\end{array}$ & $<4500$ & Small \\
\hline \multirow{2}{*}{ II } & $\begin{array}{l}\text { Xingan, Yifeng, Xiajiang, Shanggao, Shangli, Jingangshan, } \\
\text { Jizhou, Qingyuan, Gao'an, Luxi, Xiangdong }\end{array}$ & 4501-7400 & Medium \\
\hline III & $\begin{array}{l}\text { Zhangshu, Xinjian, Anyuan, Nanchang, Fenyi, Donghu, } \\
\text { Yushui, Xihu, Qingyunpu, Qingshanhu }\end{array}$ & $>7400$ & Large \\
\hline
\end{tabular}

Table 2. Sampling methods.

\begin{tabular}{cccc}
\hline Stage & Sampling Unit & Number & Method \\
\hline Frist & Town & 1 & Stratified sampling \\
Second & Neighborhood/Village & 2 & Probability proportionate to size sampling \\
Third & Resident & 12 & Simple random sampling \\
\hline
\end{tabular}

\subsection{Research Methods}

\subsubsection{Contingent Valuation Method}

Contingent valuation method is a simple and flexible nonmarket approach [38], commonly referred to as the stated preference model [39]. It is widely used for cost-benefit analysis and environmental impact assessments of nonmarket resources $[40,41]$. The method was first introduced to measure the value of outdoor leisure in the Maine backwoods of the United States [42]. Although the contingent valuation method has been criticized for the reliability and validity of the results, yet through the efforts of many scholars, the above problems have been evaded [43]. The method has been applied to assess the value for renewable energy [44], forests [15], wetlands [45], watersheds [17], hydrogen buses [46] and other nonmarket resources $[47,48]$. The induction modes for willingness to pay include open, repeat bidding, dichotomy, payment card, and so on [49], which are increasingly used to obtain the residents' WTP for environmental protection of the river basin. The payment card of the induction mode has the advantages of easy access to the respondents' willingness to pay, avoidance information deviation, and circumvention extreme values [17]. Moreover, WTP analyses usually apply to households. Therefore, this paper studies the residents' WTP and payout level in the downstream section of the Ganjiang River Basin by using the payment card (PC) contingent valuation method (CVM). Specifically, the formula is as follows.

$$
W T P_{i}=\sum_{h_{i}=1}^{T_{i}} \delta_{h_{i}} P_{h_{i}}
$$

In Equation (1), $W T P_{i}$ represents the average payout level of residents in the region $i$, and $i$ can be defined as I, II, III, and ALL. Meanwhile, $\delta_{h_{i}}$ represents the payout level for the resident $h_{i}$ of the surveyed inhabitants, $P_{h_{i}}$ represents the frequency of the payment value of the resident $h_{i}$, and $T_{i}$ represents the number of samples of the surveyed population. 


\subsubsection{Heckman's Two-Stage Model}

Heckman's two-stage model was developed by James Heckman who taught at the University of Chicago from 1976 to 1979, and was awarded the Nobel Prize in Economics for the model in 2000 [50]. Heckman's two-stage model could effectively correct the selectivity deviation, which is a unique problem of econometrics [51]. In addition, we can utilize the model to analyze the factors affecting the residents' WTP and their payout level [52].

Model selection: The ecological compensation payment activities of residents studied in this paper can be divided into two stages. The first stage is the behavioral decision stage, when the residents decide whether or not to pay for ecological compensation based on river basin environmental protection or improvement. Residents who do not have the willingness to pay are terminated as the object of the next phase of the study, and the inhabitants who have the willingness to pay enter the second stage.

The second stage is the payout level of the decision-making stage, which is the payout level of the residents who are willing to pay for the environmental protection of the river basin. Hence, this paper uses Heckman's two-stage model to analyze the influencing factors of residents' WTP and their payout level, respectively. The model is expressed as follows and contains two sub-models (Model 1 and Model 2).

Model 1 is a Probit model, which mainly examines the impacting factors for downstream residents of the Ganjiang River Basin who are willing to pay. The specific model is shown below.

$$
Y=\mu_{0}+\mu_{1} M_{1}+\mu_{2} M_{2}+\mu_{3} M_{3}+\cdots+\mu_{n} M_{n}+\theta
$$

In Equation (2), $Y$ is the explained variable; $M_{1}, M_{2}, M_{3}, \cdots, M_{n}$ are the explanatory variables; and $\mu_{0}, \mu_{1}, \mu_{2}, \mu_{3}, \cdots, \mu_{n}$ are the solve for parameters; $\theta$ being the residual parameter.

Model 2 is a multiple linear regression model, which mainly examines the influencing factors of the residents' payout level. The specific model is as follows.

$$
T=\varphi_{0}+\varphi_{1} M_{1}+\varphi_{2} M_{2}+\varphi_{3} M_{3}+\cdots+\varphi_{n} M_{n}+\varepsilon \lambda+\delta
$$

In Equation (3), $T$ is the explained variable; $M_{1}, M_{2}, M_{3}, \cdots, M_{n}$ are the independent variables; $\lambda$ represents the Mills ratio; $\varphi_{0}, \varphi_{1}, \varphi_{2}, \varphi_{3}, \cdots, \varphi_{n}$ and $\varepsilon$ are the solve-for parameters; and $\delta$ is the residual parameter.

Variables: On the basis of reference literature and combined with the specific situation of the Ganjiang River Basin in Jiangxi Province, ten indicators/variables are designed to evaluate the changes in the residents' WTP and their payout level of the Ganjiang River Basin as shown in Table 3. Meanwhile, Table 4 shows the descriptive statistics of variables applied to Heckman two-stage estimation. Table A2 in the appendix briefly shows the correlation between variables is weak.

\begin{tabular}{|c|c|c|c|}
\hline Variable & Unit/Assignment & Description & $\begin{array}{l}\text { Supporting } \\
\text { Documents }\end{array}$ \\
\hline Age $\left(M_{1}\right)$ & Years & \multirow{4}{*}{$\begin{array}{l}\text { We explore whether individual } \\
\text { information have an impact on the } \\
\text { residents' WTP and their payout level. }\end{array}$} & [25] \\
\hline Gender $\left(M_{2}\right)$ & Male $=1$, Female $=2$ & & [25] \\
\hline Education situation $\left(M_{3}\right)$ & $\begin{array}{l}\text { Grades } 1-6=1, \text { Grades } 7-9=2, \\
\text { Grades } 10-12=3, \text { Grades } 13-16=4, \\
\text { Grades } 17-19=5, \text { Grades } 20+=6\end{array}$ & & [25] \\
\hline Work type $\left(M_{4}\right)$ & $\begin{array}{l}\text { State organs }=1, \text { Public institution }=2, \\
\text { State-owned enterprises }=3, \\
\text { Private Enterprise }=4, \text { Foreign-owned } \\
\text { enterprise }=5, \text { Individual household }=6 \text {, } \\
\text { Agricultural production }=7, \\
\text { Freelancers }=8, \text { Others }=9\end{array}$ & & [17] \\
\hline
\end{tabular}

Table 3. Variables' description and interpretation. 
Table 3. Cont.

\begin{tabular}{|c|c|c|c|}
\hline Variable & Unit/Assignment & Description & $\begin{array}{l}\text { Supporting } \\
\text { Documents }\end{array}$ \\
\hline $\begin{array}{c}\text { Household annual } \\
\text { disposable income }\left(M_{5}\right)\end{array}$ & $\begin{array}{l}\text { Less than or equal to } \$ 750=1, \\
\$ 751-1500=2, \$ 1501-3000=3, \\
\$ 3001-4500=4, \$ 4501-6000=5 \\
\$ 6001-7500=6, \$ 7501-9000=7, \\
\$ 9001-10,500=8, \$ 10,501-12,000=9, \\
\$ 12,001-13,500=10, \$ 13,501-15,000=11 \\
\text { More than } \$ 15,000=12\end{array}$ & \multirow[t]{3}{*}{$\begin{array}{l}\text { We discuss whether household } \\
\text { information influences the residents' } \\
\text { WTP and their payout level. }\end{array}$} & [17] \\
\hline $\begin{array}{l}\text { Number of family } \\
\text { members }\left(M_{6}\right)\end{array}$ & Persons & & [17] \\
\hline Residential location $\left(M_{7}\right)$ & Region I = 1, Region II = 2, Region III = 3 & & [53] \\
\hline Value recognition $\left(M_{8}\right)$ & Identification $=1$, Misidentification $=2$ & $\begin{array}{l}\text { We evaluate whether the variable has } \\
\text { an impact on the residents' WTP and } \\
\text { their payout level. }\end{array}$ & [25] \\
\hline Water quality $\left(M_{9}\right)$ & $\begin{array}{l}\text { Very dissatisfied }=1, \text { Dissatisfied }=2, \\
\text { Normal }=3, \text { Satisfied }=4, \text { Very satisfied }=5\end{array}$ & \multirow{2}{*}{$\begin{array}{l}\text { We examine whether the degree of } \\
\text { satisfaction of the residents for water } \\
\text { quality and quantity affect the residents' } \\
\text { WTP and their payout level. }\end{array}$} & [17] \\
\hline Water quantity $\left(M_{10}\right)$ & $\begin{array}{l}\text { Very dissatisfied }=1, \text { Dissatisfied }=2, \\
\text { Normal }=3 \text {, Satisfied }=4 \text {, Very satisfied }=5\end{array}$ & & [17] \\
\hline
\end{tabular}

Table 4. Descriptive statistics for variables.

\begin{tabular}{cccccc}
\hline Variable & Observations & Minimal & Maximal & Mean & Standard Deviation \\
\hline$M_{1}$ & 773 & 16 & 73 & 35.37 & 9.67 \\
$M_{2}$ & 773 & 1 & 2 & 1.46 & 0.50 \\
$M_{3}$ & 773 & 1 & 6 & 3.82 & 1.56 \\
$M_{4}$ & 773 & 1 & 9 & 4.95 & 2.40 \\
$M_{5}$ & 773 & 1 & 12 & 4.99 & 3.36 \\
$M_{6}$ & 773 & 1 & 9 & 4.07 & 1.12 \\
$M_{7}$ & 773 & 1 & 3 & 1.96 & 0.80 \\
$M_{8}$ & 773 & 1 & 2 & 1.47 & 0.50 \\
$M_{9}$ & 773 & 1 & 5 & 2.83 & 1.49 \\
$M_{10}$ & 773 & 1 & 5 & 2.85 & 1.51 \\
\hline
\end{tabular}

\section{Empirical Research}

\subsection{Willingness to Pay and Payout Level}

A total of 580 residents had a positive WTP, while 193 residents did not, and the two accounted for $75.03 \%$ and $24.97 \%$, respectively, as suggested in Table 5. It shows that if the ecological environment of the Ganjiang River Basin is improved, the vast majority of the downstream residents will have a positive WTP.

Table 5. Frequency of willingness to pay (WTP) for the downstream residents.

\begin{tabular}{cccc}
\hline WTP & Number & Sample Size & Proportion \\
\hline YES & 1 & 580 & $75.03 \%$ \\
NO & 0 & 193 & $24.97 \%$ \\
\hline
\end{tabular}

In the survey of the downstream residents, we found that the residents who have a willingness to pay do so due to the improvement in the Ganjiang River Basin, which to some extent makes upstream residents lose the right to develop, and makes the downstream ecological environment better. However, the residents who do not have the willingness to pay mentioned that they have already paid taxes and fees to the government, so compensation should be borne by the government.

We substitute the collected data into Equation (1), and the results are shown below (in order to make downstream residents' payout level clearer, we converted Chinese yuan into US dollars. 
Meanwhile, the value measured as the Chinese currency (RMB Yuan) is converted into US dollar value by the average exchange rate during 2016 (RMB 6.6423 yuan to one dollar) per household per year).

$$
\begin{gathered}
\mathrm{E}\left(W T P_{I}\right)=\sum_{h_{I}=1}^{T_{I}} \delta_{h_{I}} P_{h_{I}}=\$ 13.20 \\
\mathrm{E}\left(W T P_{I I}\right)=\sum_{h_{I I}=1}^{T_{I I}} \delta_{h_{I I}} P_{h_{I I}}=\$ 46.80 \\
\mathrm{E}\left(W T P_{I I I}\right)=\sum_{h_{I I I}=1}^{T_{I I I}} \delta_{h_{I I I}} P_{h_{I I I}}=\$ 87.66 \\
\mathrm{E}\left(W T P_{A L L}\right)=\sum_{h_{A L L}=1}^{T_{A L L}} \delta_{h_{A L L}} P_{h_{A L L}}=\$ 47.62
\end{gathered}
$$

The research findings in Figure 2 and Equations (4)-(7) indicate that the payout level of the average household for the ecological protection of the Ganjiang River Basin is $\$ 47.62$ every year. The lowest payout level of the average household is $\$ 13.20$ annually, which happens in region $I$. The highest payout level of the average household is $\$ 87.66$ annually, which appears in region III. The intermediate payout level of the average household is $\$ 46.80$ annually, which occurs in region II. As a consequence, the results reveal that bigger the regional per capita GDP, higher is the residents' payout level for ecological compensation.

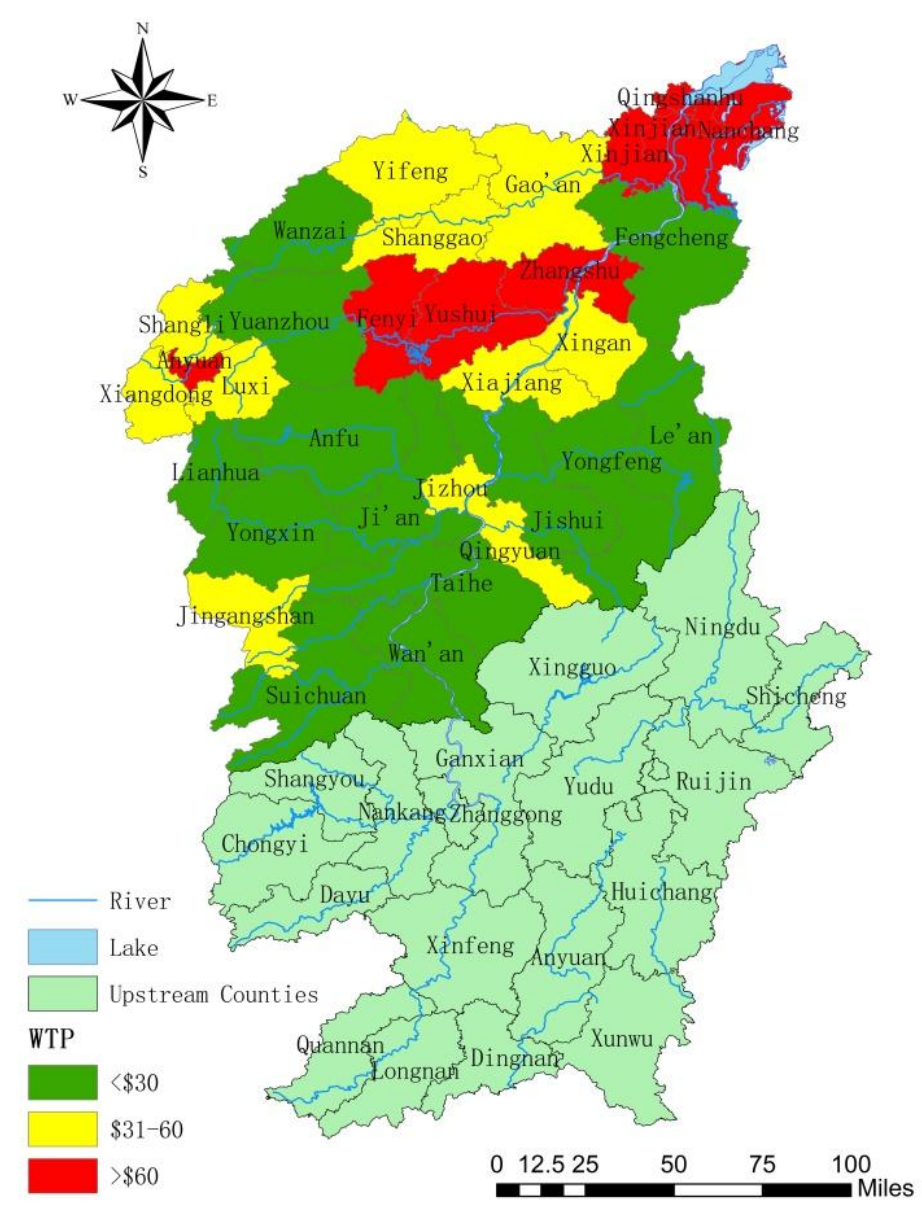

Figure 2. The payout levels for the downstream residents of the Ganjiang River Basin. 


\subsection{Results of the Regressions}

Using the Stata12.0 software platform, Heckman's two-stage model was used to study the factors affecting WTP and payout level of the residents' who are living in the lower reaches of the Ganjiang River Basin. The residents' WTP and their payout level were regarded as dependent variables and the independent variables were respondents' characteristics. The empirical findings are shown in the following table.

According to the data in Table 6, it can be found that the value of Wald is 533.96 and the $P$ value is 0 , indicating that rejecting the original hypothesis and the whole model is effective.

Table 6. Model validity analysis.

\begin{tabular}{ccccc}
\hline Observations & Restricted Observations & Unrestricted Observations & Wald & $\boldsymbol{P}>|\mathrm{z}|$ \\
\hline 773 & 193 & 580 & 533.96 & 0.000 \\
\hline
\end{tabular}

It needs to be emphasized that there are ten explanatory variables in Heckman's first-stage model, while only seven explanatory variables are incorporated in Heckman's second-stage model. The reason is that the number of variables in the second stage must be less than the number in the first stage. In accordance with this principle, we excluded three explanatory variables $\left(M_{1}, M_{2}\right.$, and $\left.M_{6}\right)$ in the second stage, which are not statistically significant with the residents' WTP and their payout level.

\subsection{Factors Influencing the Residents' WTP}

The empirical results indicated in Table 7 reveal that the education situation $\left(M_{3}\right)$, work type $\left(M_{4}\right)$, residential location $\left(M_{7}\right)$, water quality $\left(M_{9}\right)$, and water quantity $\left(M_{10}\right)$ have significant correlation with the residents' WTP, nevertheless the age $\left(M_{1}\right)$, gender $\left(M_{2}\right)$, household annual disposable income $\left(M_{5}\right)$, and number of family members $\left(M_{6}\right)$ did not show statistical significance. In addition, the value recognition $\left(M_{8}\right)$ was marginally significant to WTP.

Table 7. Heckman's first-stage model (Probit model/selection model) estimation results.

\begin{tabular}{ccccc}
\hline Variable & Coef. & Std. Err. & $\mathbf{Z}$ & $\boldsymbol{P}>|\mathbf{z}|$ \\
\hline$M_{1}$ & -0.001 & 0.010 & -0.050 & 0.959 \\
$M_{2}$ & 0.242 & 0.188 & 1.290 & 0.198 \\
$M_{3}$ & $0.309^{* * *}$ & 0.091 & 3.410 & 0.001 \\
$M_{4}$ & $-0.089^{*}$ & 0.051 & -1.750 & 0.081 \\
$M_{5}$ & -0.032 & 0.037 & -0.870 & 0.383 \\
$M_{6}$ & 0.061 & 0.079 & 0.770 & 0.441 \\
$M_{7}$ & $0.287^{* *}$ & 0.134 & 2.140 & 0.032 \\
$M_{8}$ & -0.168 & 0.104 & -1.610 & 0.107 \\
$M_{9}$ & $0.967^{* * *}$ & 0.202 & 4.780 & 0.000 \\
$M_{10}$ & $1.070^{* * *}$ & 0.216 & 4.950 & 0.000 \\
Constant & $-3.990^{* * *}$ & 0.882 & -4.520 & 0.000 \\
\hline Note: ***, and $* * *$ represent the significance at $10 \%, 5 \%$, and $1 \%$, respectively.
\end{tabular}

$M_{3}$ has significant positive correlation with the residents' WTP, which means that higher the residents' education levels become, the stronger they are willing to pay. It may be that with the number of years of education increasing, residents are able to understand the importance of the ecological environment of the river basin for production and living. As a consequence, they have a stronger WTP for the ecological compensation of the river basin. $M_{4}$ has significant negative correlation with the residents' WTP, which indicates that residents with stable work have a stronger willingness to pay. It may be that the residents with relatively stable work have relatively stable income, pay more attention to the quality of life, and are therefore more concerned about the ecological environment of the Ganjiang River Basin. Consequently, the residents have a stronger willingness to pay in order 
to improve the ecological environment of the river basin. $M_{7}$ is significantly positively related to the residents' WTP, which means that the residents living in Region III with higher per capita GDP have a stronger WTP for ecological protection of the river basin. It may be that the residents who are living in the areas with higher per capita GDP are more focused on the impact of the ecological environment to their own body. As a result, the residents with higher per capita GDP are more willing to pay for the improvement of the ecological environment. $M_{8}$ is marginally significant with residents' WTP, indicating that the residents who consider that the Ganjiang River Basin has a huge ecological value can better understand its importance. Thus, in order to protect and improve the ecological environment of the Ganjiang River Basin, they have a stronger willingness to pay. $M_{9}$ and $M_{10}$ are significantly positively related to the residents' WTP. Therefore, the residents who are more satisfied with the water quality and quantity of the Ganjiang River Basin have a stronger WTP. The reason is that residents who are happier with the water quality and quantity will be able to get more from the Ganjiang River Basin water resources. With the purpose of protecting or improving existing water quality and quantity, they will have a stronger WTP.

\subsection{Factors Influencing the Residents' Payout Level}

The empirical findings revealed in Table 8 show that the education situation $\left(M_{3}\right)$, work type $\left(M_{4}\right)$, household annual disposable income $\left(M_{5}\right)$, water quality $\left(M_{9}\right)$, and water quantity $\left(M_{10}\right)$ are significantly related to the residents' payout level, while the residential location $\left(M_{7}\right)$ does not show statistical significance. Besides, value recognition $\left(M_{8}\right)$ shows a marginal significant correlation with their payout level.

Table 8. Heckman's second-stage model (OLS model/payment model) estimation results.

\begin{tabular}{ccccc}
\hline Variable & Coef. & Std. Err. & $\mathbf{Z}$ & $\boldsymbol{P}>|\mathbf{z}|$ \\
\hline$M_{3}$ & $0.660^{* * *}$ & 0.167 & 3.980 & 0.000 \\
$M_{4}$ & $-0.481^{* * *}$ & 0.089 & -5.400 & 0.000 \\
$M_{5}$ & $0.185^{* * *}$ & 0.067 & 2.750 & 0.006 \\
$M_{7}$ & 0.203 & 0.272 & 0.740 & 0.456 \\
$M_{8}$ & -0.392 & 0.285 & -1.380 & 0.169 \\
$M_{9}$ & $1.830^{* * *}$ & 0.291 & 6.290 & 0.000 \\
$M_{10}$ & $1.516^{* * *}$ & 0.279 & 5.420 & 0.000 \\
Constant & $-2.796^{* *}$ & 1.297 & -2.160 & 0.031 \\
$\lambda$ & $3.630^{* * *}$ & 0.605 & 5.990 & 0.000 \\
rho & 0.821 & & & \\
sigma & 4.423 & & & \\
\hline Note: **, and ${ }^{* * *}$ represent the significance at 5\%, and 1\%, respectively.
\end{tabular}

$M_{3}$ had significant positive correlation with the residents' payout level, which means that with the improvement of education levels, the residents who have a positive willingness to pay will have a higher payout level. It may be that the perception and sensitivity to the ecological environment of the residents who have a higher degree of education will be stronger, which makes them willing to pay a higher payout level. $M_{4}$ has significant negative correlation with the residents' payout level, indicating that the residents possessing a stable job have a higher payout level. This may be because when the residents' work in public institutions or state-owned enterprises, they can get a stable and considerable income and are therefore more likely to be concerned about the ecological compensation of the river basin. This might result in a higher payout level. $M_{5}$ is significantly positively related to the residents' payout level, illustrating that the more the household annual disposable income of the residents who have a positive willingness to pay, higher is their payout level. The reason is that the households with higher disposable incomes are able to have more income to protect and improve the ecological environment of the Ganjiang River Basin. $M_{8}$ is marginally significant with the residents' payout level, which indicates that the residents, who have the willingness to pay, recognize the value 
of the Ganjiang River Basin and these residents have a higher payout level than those who do not recognize the value. $M_{9}$ and $M_{10}$ are significantly positively related to the residents' payout level. This may be because the residents who have a positive willingness to pay are more satisfied with the water quality and quantity of Ganjiang, indicating that the water resources environment of the Ganjiang River Basin meets the needs of the residents. Thus, the better the water environment of the Ganjiang River Basin, the higher is the residents' payout level. Meanwhile, $\lambda$ shows statistical significance, indicating that the sample does have a selection bias. As a consequence, this result strengthens the necessity of using the Heckman's two-step model.

\section{Research Conclusions}

We use the household-level survey data and adopt the CVM and Heckman's two-step model to examine the determinants of the residents' WTP and their payout level for ecological protection in the downstream section of the Ganjiang River Basin.

The results show that $75.03 \%$ of the surveyed residents have a positive WTP for ecological protection of the river basin. Meanwhile, the residents who are living in the lower reaches of the basin have a willingness to pay an annual average of about $\$ 47.62 /$ household for ecological compensation. The education background, work type, residential location, and water quality and quantity are significantly related to the residents' WTP. The education background, work type, household annual disposable income, and water quality and quantity are also significantly correlated with their payout level. In addition, the value recognition is marginally significant related to the residents' WTP and payout level.

It is important to establish the compensation mechanism for the watershed ecology of the Ganjiang River Basin. On the basis of the above statement, an important factor is the compensation fund. If we only rely on the unilateral power of the government, there will be a shortage of funds, so we need to fully mobilize the majority of residents to participate in the ecological preservation of the Ganjiang River Basin. In order to effectively raise the residents' WTP and payout level, we can also promote the ecological protection of the Ganjiang River Basin. Thus, the following five suggestions are put forward.

First, the government should intensify its propaganda about the ecological value of the Ganjiang River Basin. From the empirical results, we find that people who recognized the ecological value of the river basin were more willing to pay for ecological compensation and have a higher payout level. Therefore, in order to enhance the residents' awareness of the ecological environment, the government should propagate the important values of the Ganjiang River Basin through television, radio, newspaper, internet, and other media. Only in this way can we improve the residents' WTP and payout level for the ecological protection of the Ganjiang River Basin.

Second, it is important for us to further promote the investment in education funding. What we can conclude from the empirical results is that higher the residents' education levels, stronger is their willingness to pay. Consequently, we need to increase the investment in education, mostly aimed at primary and secondary school students. We should set up related courses about environmental protection and establish awareness of the ecology of the Ganjiang River Basin. We should target children during their adolescence, in order to lay a solid foundation for the future. Meanwhile, we can increase the investment in higher education and continuing re-education in the lower reaches of the river basin, allowing more downstream residents to accept further education, so that more and more people will provide ecological compensation for the Ganjiang River Basin.

Third, we should continue to improve the regional economic levels and per capita income. The empirical results show that the residents' WTP and payout levels are becoming higher as the per capita GDP increases. Therefore, we must vigorously develop the economy, especially the development of ecological services, in order to meet the requirements of ecological and environmental protection. Meanwhile, we also find that higher the household annual disposable income of the residents, higher is their payout level. In consequence, the government needs to raise the income of the residents as much 
as possible and constantly motivate residents to increase income channels and continuously enhance the residents' satisfaction and happiness, so that more and more residents will join the ecological protection of the watershed.

Fourth, establish a variety of payment patterns for ecological compensation. In the questionnaire, we find that most residents who have positive WTP want to pay by means of the ecological tax, utility bills, donations or intellectual compensation instead of paying directly by currency. Hence, the government needs to establish diversified modes of payment for the ecological protection of the Ganjiang River Basin. The government can levy ecological tax or take a portion of utility bills from the downstream residents to compensate the upstream residents and government who provide the positive externalities so that the promotion of the environmental sustainability for the Ganjiang River Basin may be achieved.

Fifth, we should strive to protect and stabilize the water quality and quantity of the Ganjiang River Basin. Through the empirical results, we realize that when the residents are happy with the water quality and quantity, they have a stronger WTP. The government should establish the Management Coordination Commission of the Ganjiang River Basin, which is responsible for formulating relevant development policy and strategic planning for the river basin. At the same time, the government must actively build the authority of the Ganjiang River Basin, which is in charge of the management, so as to improve the water quality and quantity of the river. Thus, we can promote the residents' willingness to pay and make a positive contribution to the protection of the river basin.

Author Contributions: K.X. collected the study data and made great efforts for the model specification and empirical study; F.K. made a great contribution for the determination of the research framework; N.Z. revised the manuscript; N.L. and C.S. put forward some improvement suggestions. All authors read and approved the final manuscript.

Funding: National Social Science Fund of China (18AJY006), National Science Foundation of China (41261110), China Postdoctoral Science Foundation (2017M612146), Jiangxi Social Science Research 2017 Annual Plan Project (17YJ39), 2017 Research Project of Humanities and Social Sciences of Jiangxi Province (JJ17222), Science and Technology Project of Jiangxi Education Department (GJJ151098).

Acknowledgments: This article was supported by the Science and Technology Project of Jiangxi Education Department (GJJ151098), 2017 Research Project of Humanities and Social Sciences of Jiangxi Province (JJ17222), Jiangxi Social Science Research 2017 Annual Plan Project (17YJ39), China Postdoctoral Science Foundation (2017M612146), National Science Foundation of China (41261110), National Social Science Fund of China (18AJY006).

Conflicts of Interest: The authors declare no conflict of interest.

\section{Appendix A}

Table A1. Major questions about the ecological compensation of Ganjiang River Basin.

\begin{tabular}{cll}
\hline \multicolumn{1}{c}{ Category } & \multicolumn{1}{c}{ Questions } & \multicolumn{1}{c}{ Answers } \\
\hline & $\begin{array}{l}\text { Age; Gender; Education situation; } \\
\text { Work type; Household annual disposable } \\
\text { income; Number of family members; } \\
\text { Residential location; Value recognition; } \\
\text { Water quality; Water quantity. }\end{array}$ & $\begin{array}{l}\text { Keeping a record in accordance with } \\
\text { the specific situation. }\end{array}$ \\
\hline & $\begin{array}{l}\text { In order to protect and improve the } \\
\text { ecological environment of the river basin, } \\
\text { we assume that the government will } \\
\text { increase the funds invested in the }\end{array}$ & Yes, I have the WTP. \\
& $\begin{array}{l}\text { Ganjiang River Basin. Therefore, we ask } \\
\text { the question is "Do you have the willing } \\
\text { to pay for the government's protection?" }\end{array}$ & \\
\hline
\end{tabular}


Table A1. Cont.

\begin{tabular}{|c|c|c|}
\hline Category & Questions & Answers \\
\hline \multirow[b]{2}{*}{ The elicitation questions for WTP } & $\begin{array}{l}\text { If the answer is "Yes, I have the WTP", } \\
\text { then we will ask: how much are you } \\
\text { willing to pay for the ecological protection } \\
\text { of Ganjiang River Basin (Chinese Yuan). }\end{array}$ & $\begin{array}{l}\text { The interviewee chooses a payment } \\
\text { amount in the payment card. }\end{array}$ \\
\hline & $\begin{array}{l}\text { If the answer is "No, I don't have the } \\
\text { WTP", then we will ask: what is } \\
\text { the reason. }\end{array}$ & $\begin{array}{l}\text { The environmental protection of } \\
\text { Ganjiang River Basin is what the } \\
\text { government should do. } \\
\text { We have no need to pay for the } \\
\text { ecological protection of Ganjiang } \\
\text { River Basin, because it doesn't have a } \\
\text { negative impact on me. } \\
\text { I've already paid taxes, and I } \\
\text { shouldn't have to pay for it. }\end{array}$ \\
\hline $\begin{array}{l}\text { The questions for } \\
\text { payment methods }\end{array}$ & $\begin{array}{l}\text { If the answer is "Yes, I have the WTP", } \\
\text { we are going to ask the question is } \\
\text { "Which method of payment will } \\
\text { you adopt?" }\end{array}$ & $\begin{array}{l}\text { The main answers are the ecological } \\
\text { tax, utility bills, donations, } \\
\text { intellectual compensation and so on. }\end{array}$ \\
\hline
\end{tabular}

Note: It is important to note that some other questions are also involved in the questionnaire survey, for the sake of comprehensively investigating the residents' attitude on the ecological compensation of the Ganjiang River Basin. We do not make a list of all questions in the Table A1 on account of the space constraint. Other questions are designed for researching related ecological compensation of the Ganjiang River Basin, which are used for the further study.

Table A2. Variable correlation analysis.

\begin{tabular}{|c|c|c|c|c|c|c|c|}
\hline & & $M_{3}$ & $M_{4}$ & $M_{5}$ & $M_{6}$ & $M_{7}$ & $M_{8}$ \\
\hline \multirow[t]{3}{*}{$M_{3}$} & Pearson & 1 & $-0.494 *$ & 0.560 * & $-0.121 *$ & 0.282 * & -0.245 \\
\hline & Sig. & & 0.000 & 0.000 & 0.001 & 0.000 & 0.000 \\
\hline & $\mathrm{N}$ & 773 & 773 & 773 & 773 & 773 & 773 \\
\hline \multirow[t]{3}{*}{$M_{4}$} & Pearson & $-0.494^{*}$ & 1 & -0.410 * & $0.105^{*}$ & $-0.299 *$ & 0.239 * \\
\hline & Sig. & 0.000 & & 0.000 & 0.003 & 0.000 & 0.000 \\
\hline & $\mathrm{N}$ & 773 & 773 & 773 & 773 & 773 & 773 \\
\hline \multirow[t]{3}{*}{$M_{5}$} & Pearson & 0.560 * & $-0.410 *$ & 1 & $-0.235^{*}$ & $0.207^{*}$ & -0.172 * \\
\hline & Sig. & 0.000 & 0.000 & & 0.000 & 0.000 & 0.000 \\
\hline & $\mathrm{N}$ & 773 & 773 & 773 & 773 & 773 & 773 \\
\hline \multirow[t]{3}{*}{$M_{6}$} & Pearson & $-0.121 *$ & 0.105 * & $-0.235^{*}$ & 1 & $-0.097 *$ & 0.046 \\
\hline & Sig. & 0.001 & 0.003 & 0.000 & & 0.007 & 0.205 \\
\hline & $\mathrm{N}$ & 773 & 773 & 773 & 773 & 773 & 773 \\
\hline \multirow[t]{3}{*}{$M_{7}$} & Pearson & 0.282 & $-0.299 *$ & $0.207^{*}$ & $-0.097^{*}$ & 1 & -0.180 * \\
\hline & Sig. & 0.000 & 0.000 & 0.000 & 0.007 & & 0.000 \\
\hline & $\mathrm{N}$ & 773 & 773 & 773 & 773 & 773 & 773 \\
\hline \multirow[t]{3}{*}{$M_{8}$} & Pearson & $-0.245^{*}$ & 0.239 * & $-0.172 *$ & 0.046 & $-0.180 *$ & 1 \\
\hline & Sig. & 0.000 & 0.000 & 0.000 & 0.205 & 0.000 & \\
\hline & $\mathrm{N}$ & 773 & 773 & 773 & 773 & 773 & 773 \\
\hline
\end{tabular}

Note: We have calculated the correlation between variables, as shown in Table A2. Except for the lack of correlation between $M_{6}$ and $M_{8}$, there are correlations among other variables. However, Pearson correlation coefficients are not high. That is, correlation between variables is weak. Meanwhile, ${ }^{*}$ represents the significance at $1 \%$.

\section{References}

1. Guo, Y.; Huang, C.C.; Zhou, Y.; Pang, J.; Zha, X.; Fan, L.; Mao, P. Sedimentary record and luminescence chronology of palaeoflood events along the Gold Gorge of the upper Hanjiang River, middle Yangtze River basin, China. J. Asian Earth Sci. 2018, 156, 96-110. [CrossRef]

2. Guo, Y.; Xia, X.; Zhang, S.; Zhang, D. Environmental Regulation, Government R\&D Funding and Green Technology Innovation: Evidence from China Provincial Data. Sustainability 2018, 10, 940. 
3. Wang, B.; Gao, P.; Niu, X.; Sun, J. Policy-driven China's Grain to Green Program: Implications for ecosystem services. Ecosyst. Serv. 2017, 27, 38-47. [CrossRef]

4. Zhang, Q.; Zhang, Z.; Shi, P.; Singh, V.P.; Gu, X. Evaluation of ecological instream flow considering hydrological alterations in the Yellow River basin, China. Glob. Planet. Chang. 2018, 160, 61-74. [CrossRef]

5. Huan, Q.Z.; Xu, Y. Construction of the ecological civilization demonstration area from the three-dimensional perspective: Evaluation and prospect. J. China Univ. Geosci. (Soc. Sci. Ed.) 2017, 17, 54-63.

6. People's Government of Jiangxi Province. The Implementation Scheme of River Basin Ecological Compensation in Jiangxi Province (Trial). Available online: http://www.jiangxi.gov.cn/zzc/ajg/szf/201512/t20151229_ 1239219.htm (accessed on 1 November 2015).

7. State Council of the PRC. The Notice of the State Council on the Action Plan for the Prevention and Control of Water Pollution. Available online: http:/ / www.gov.cn/zhengce/content/2015-04/16/content_9613.htm (accessed on 2 April 2015).

8. Ministry of Agriculture of the People's Republic of China. CPC No.1 Document. Available online: http:/ / english.agri.gov.cn/hottopics/cpc/ (accessed on 6 February 2017).

9. Li, F.; Pan, B.; Wu, Y.; Shan, L. Application of game model for stakeholder management in construction of ecological corridors: A case study on Yangtze River Basin in China. Habitat Int. 2017, 63, 113-121. [CrossRef]

10. Chen, M.; Lu, Y.; Ling, L.; Wan, Y.; Luo, Z.; Huang, H. Drivers of changes in ecosystem service values in Ganjiang upstream watershed. Land Use Policy 2015, 47, 247-252. [CrossRef]

11. Chen, M.Q.; Zhao, B.P.; Luo, Z.J.; Huang, H.S.; Wei, X.H.; Lu, T.G.; Xu, L. The ecosystem services value change in the upper reaches of Ganjiang River Based on RS and GIS. Acta Ecol. Sin. 2013, 33, 2761-2767. [CrossRef]

12. Lynch, B.D. Vulnerabilities, competition and rights in a context of climate change toward equitable water governance in Peru's Rio Santa Valley. Glob. Environ. Chang. 2012, 22, 364-373. [CrossRef]

13. Nzung'a, S.O.; Pan, W.; Shen, T.; Li, W.; Qin, X.; Wang, C.; Zhang, L.; Yu, L. Comparative study of carbonic anhydrase activity in waters among different geological eco-environments of Yangtze River basin and its ecological significance. J. Environ. Sci. 2018, 66, 173-181. [CrossRef] [PubMed]

14. Ma, J.; Liu, Y.; Wang, H.; Yan, D.H.; Lv, Y.K.; Yang, Z. Socioeconomic impacts of hydropower development on the Yibin-Chongqing section, upper reaches of the Yangtze River. Phys. Chem. Earth Parts A/B/C 2015, 89, 73-78. [CrossRef]

15. Henry, M.; Mittelhammer, R.C.; Loomis, J.B. An information theoretic approach to estimating willingness to pay for river recreation site attributes. Water Resour. Econ. 2018, 21, 17-28. [CrossRef]

16. Chatterjee, C.; Triplett, R.; Johnson, C.K.; Ahmed, P. Willingness to pay for safe drinking water: A contingent valuation study in Jacksonville, FL. J. Environ. Manag. 2017, 203, 413-421. [CrossRef] [PubMed]

17. Zhou, C.; Li, G.P. The Influencing Factors for Willingness to Pay of Payment for Watershed Services: A Case of the Water Receiving Area of Zhengzhou City of the Middle Route Project of the South-North Water Transfer Project. Econ. Geogr. 2015, 6, 38-46.

18. Larsen, M.C. Contemporary human uses of tropical forested watersheds and riparian corridors: Ecosystem services and hazard mitigation, with examples from Panama, Puerto Rico, and Venezuela. Quat. Int. 2017, 448, 190-200. [CrossRef]

19. Ryan, M.; Watson, V. Comparing welfare estimates from payment card contingent valuation and discrete choice experiments. Health Econ. 2009, 18, 389-401. [CrossRef] [PubMed]

20. Bhandari, P.; Mohan, K.C.; Shrestha, S.; Aryal, A.; Shrestha, U.B. Assessments of ecosystem service indicators and stakeholder's willingness to pay for selected ecosystem services in the Chure region of Nepal. Appl. Geogr. 2016, 69, 25-34. [CrossRef]

21. Moreno-Sanchez, R.; Maldonado, J.H.; Wunder, S.; Borda-Almanza, C. Heterogeneous users and willingness to pay in an ongoing payment for watershed protection initiative in the Colombian Andes. Ecol. Econ. 2012, 75, 126-134. [CrossRef]

22. Van Hecken, G.; Bastiaensen, J.; Vásquez, W.F. The viability of local payments for watershed services: Empirical evidence from Matiguás, Nicaragua. Ecol. Econ. 2012, 74, 169-176. [CrossRef]

23. Li, C.X.; Peng, F.Q.; Chen, H. Analysis of the Influencing Factors for Willingness to Pay of Payment for Ecosystem Services of River Basin: A Case of Changsha Reach of Xiang Jiang River Basin. Econ. Geogr. 2012, 4, 130-135.

24. Guan, X.; Liu, W.; Chen, M. Study on the ecological compensation standard for river basin water environment based on total pollutants control. Ecol. Indic. 2016, 69, 446-452. [CrossRef] 
25. Zheng, H.X.; Zhang, L.B.; Tu, Q. Analysis of the People's Willingness to Pay for Environmental Services Compensation and Its Influence Factors in the Jinhua River Basin. Resour. Sci. 2010, 4, 761-767.

26. Ge, Y.X.; Liang, L.J.; Wang, B.B.; Wu, F.F. Analysis of the Influencing Factors for Residents' Willingness to Pay and payment levels for Ecological Compensation of Yellow River Basin: A Case of Shandong Province. Chin. Rural Econ. 2009, 10, 77-85.

27. Sellers-Rubio, R.; Nicolau-Gonzalbez, J.L. Estimating the willingness to pay for a sustainable wine using a Heckit model. Wine Econ. Policy 2016, 5, 96-104. [CrossRef]

28. Lyu, S.O.; Noh, E.J. Shopping decisions of international tourists to Korea: The Heckman sample selection approach. J. Destin. Mark. Manag. 2017, 6, 436-443. [CrossRef]

29. Li, N.; Tang, G.; Zhao, P.; Hong, Y.; Gou, Y.; Yang, K. Statistical assessment and hydrological utility of the latest multi-satellite precipitation analysis IMERG in Ganjiang River basin. Atmos. Res. 2017, 183, 212-223. [CrossRef]

30. Bing, H.; Wu, Y.; Liu, E.; Yang, X. Assessment of heavy metal enrichment and its human impact in lacustrine sediments from four lakes in the mid-low reaches of the Yangtze River, China. J. Environ. Sci. 2013, 25, 1300-1309. [CrossRef]

31. Zhou, Y.; Jin, S.; Tenzer, R.; Feng, J. Water storage variations in the Poyang Lake Basin estimated from GRACE and satellite altimetry. Geod. Geodyn. 2016, 7, 108-116. [CrossRef]

32. Jin, Z.K.; Gao, B.S.; Wang, J.Y.; Li, Y.; Shi, L.; Yu, K.H.; Li, G.Z. Two new types of sandbars in channels of the modern Ganjiang Delta, Poyang Lake, China: Depositional characteristics and origin. J. Palaeogeogr. 2017, 6, 132-143. [CrossRef]

33. Zhang, Z.; Chen, X.; Xu, C.Y.; Hong, Y.; Hardy, J.; Sun, Z. Examining the influence of river-lake interaction on the drought and water resources in the Poyang Lake basin. J. Hydrol. 2015, 522, 510-521. [CrossRef]

34. Hu, Q.; Feng, S.; Guo, H.; Chen, G.; Jiang, T. Interactions of the Yangtze river flow and hydrologic processes of the Poyang Lake, China. J. Hydrol. 2007, 347, 90-100. [CrossRef]

35. Zhang, X.; Kuchinke, L.; Woud, M.L.; Velten, J.; Margraf, J. Survey method matters: Online/offline questionnaires and face-to-face or telephone interviews differ. Comput. Hum. Behav. 2017, 71, 172-180. [CrossRef]

36. Liu, M. Data collection mode differences between national face-to-face and web surveys on gender inequality and discrimination questions. Women's Stud. Int. Forum 2017, 60, 11-16. [CrossRef]

37. Sun, C.; Nan, L.; Ouyang, X. Chinese Public Willingness to Pay to Avoid Having Nuclear Power Plants in the Neighborhood. Sustainability 2014, 6, 7197-7223. [CrossRef]

38. Xie, B.; Zhao, W. Willingness to pay for green electricity in Tianjin, China: Based on the contingent valuation method. Energy Policy 2018, 114, 98-107. [CrossRef]

39. Whitehead, J.C. A comment on "Three reasons to use annual payments in contingent valuation". J. Environ. Econ. Manag. 2018, 88, 486-488. [CrossRef]

40. Venkatachalam, L. The contingent valuation method: A review. Environ. Impact Assess. Rev. 2004, 24, 89-124. [CrossRef]

41. Fogarassy, C.; Kerpely, K.; Horvath, B.; Bakosne Borocz, M. Analysing the attributes of ecological evaluation on local and regional levels via Willingness To Pay (WTP): A Hungarian case study. Appl. Ecol. Environ. Res. 2016, 14, 129-145. [CrossRef]

42. Mitchell, R.C.; Carson, R.T. Using Surveys to Value Public Goods: The Contingent Valuation Method; Resources for the Future Press: Washington, DC, USA, 1989.

43. Lee, C.; Heo, H. Estimating willingness to pay for renewable energy in South Korea using the contingent valuation method. Energy Policy 2016, 94, 150-156. [CrossRef]

44. Botelho, A.; Pinto, L.M.; Lourenço-Gomes, L.; Valente, M.; Sousa, S. Social sustainability of renewable energy sources in electricity production: An application of the contingent valuation method. Sustain. Cities Soc. 2016, 26, 429-437. [CrossRef]

45. Siew, M.K.; Yacob, M.R.; Radam, A.; Adamu, A.; Alias, E.F. Estimating Willingness to Pay for Wetland Conservation: A Contingent Valuation Study of Paya Indah Wetland, Selangor Malaysia. Procedia Environ. Sci. 2015, 30, 268-272. [CrossRef]

46. Bigerna, S.; Polinori, P. Willingness to Pay and Public Acceptance for Hydrogen Buses: A Case Study of Perugia. Sustainability 2015, 7, 13270-13289. [CrossRef]

47. Wang, J.; Ge, J.; Gao, Z. Consumers' Preferences and Derived Willingness-to-Pay for Water Supply Safety Improvement: The Analysis of Pricing and Incentive Strategies. Sustainability 2018, 10, 1704. [CrossRef] 
48. Fogarassy, C.; Neubauer, E. Evaluation of the regional water usage in Hungary with Water Allowance Coefficient (WAC). Appl. Ecol. Environ. Res. 2016, 14, 161-173. [CrossRef]

49. Lu, W.; Peng, Y.; Webster, C.; Zuo, J. Stakeholders' willingness to pay for enhanced construction waste management: A Hong Kong study. Renew. Sustain. Energy Rev. 2015, 47, 233-240. [CrossRef]

50. Heckman, J.J. Sample Selection Bias as a Specification Error. Econometrica 1979, 47, 153-161. [CrossRef]

51. Morrissey, K.; Kinderman, P.; Pontin, E.; Tai, S.; Schwannauer, M. Web based health surveys: Using a Two Step Heckman model to examine their potential for population health analysis. Soc. Sci. Med. 2016, 163, 45-53. [CrossRef] [PubMed]

52. Kim, J.; Jang, S.S. Dividend behavior of lodging firms: Heckman's two-step approach. Int. J. Hosp. Manag. 2010, 29, 413-420. [CrossRef]

53. Kong, F.B.; Xiong, K.; Zhang, N. Determinants of farmers' willingness to pay and its level for ecological Compensation of Poyang Lake Wetland, China: A Household-Level Survey. Sustainability 2014, 6, 6714-6728. [CrossRef]

(C) 2018 by the authors. Licensee MDPI, Basel, Switzerland. This article is an open access article distributed under the terms and conditions of the Creative Commons Attribution (CC BY) license (http:// creativecommons.org/licenses/by/4.0/). 